\title{
Pengaruh Pemahaman Peraturan Perpajakan Terhadap Kepatuhan WPOP Dengan Preferensi Resiko Sebagai Variabel Pemoderasi
}

\author{
Putu Devi Ayu Utari ${ }^{1}$ \\ Putu Ery Setiawan ${ }^{2}$ \\ ${ }^{1,2}$ Fakultas Ekonomi dan Bisnis Universitas Udayana (Unud), Bali, Indonesia \\ e-mail: devi.ayutari@yahoo.com
}

\begin{abstract}
ABSTRAK
Tujuan dari penelitian ini adalah untuk mengetahui penerapan pemahaman peraturan pajak terhadap kepatuhan wajib pajak orang pribadi wilayah Badung Utara. Untuk mengetahui apakah preferensi risiko dapat memoderasi hubungan antara pemahaman tentang peraturan pajak terhadap kepatuhan wajib pajak orang pribadi wilayah Badung Utara. Jumlah sampel minimal yang digunakan dalam penelitian sebanyak 100 (seratus) wajib pajak orang pribadi di KPP Pratama Badung Utara. Penelitian ini menggunakan metode accidential sampling. Metode pengumpulan data menggunakan metode angket. Teknik analisis data yang digunakan adalah Moderated Regression Analysis (MRA). Hasil yang diperoleh bahwa pemahaman peraturan perpajakan berpengaruh positif dan signifikan terhadap kepatuhan wajib pajak serta preferensi risiko dapat memoderasi hubungan pemahaman peraturan perpajakan dengan kepatuhan wajib pajak.
\end{abstract}

Kata kunci: Pemahaman Pajak, Kepatuhan Pajak, Preferensi Resiko

\begin{abstract}
Badung Utara, Badung Utara, Badung Utara. To find out whether the preference must be able to moderate the relationship between understanding of tax regulations on individual taxpayer regulations in the North Badung region. The minimum number of samples used in the study were 100 (one hundred) individual taxpayers at North Badung KPP Pratama. This study uses the accidential sampling method. The method of data collection uses the questionnaire method. The data analysis technique used is Moderated Regression Analysis (MRA). The results obtained related to understanding tax regulations, positive and significant to taxpayer obligations, as well as risk preferences can moderate the relationship of understanding tax regulations with taxpayer assistance.
\end{abstract}

Keywords: Understanding of Taxes, Tax Compliance, Risk Preference

\section{PENDAHULUAN}

Perkembangan perekonomian Indonesia saat ini diiringi dengan pembiayaan belanja negara yang semakin lama semakin bertambah besar. Hal ini dapat dilihat pada semakin banyaknya fasilitas-fasilitas dalam negeri yang semakin banyak dan menghabiskan banyak biaya. Hal ini menunjukkan bahwa semua pembelanjaan negara harus dibiayai dari pendapatan negara, yaitu penerimaan dari pajak dan 
penerimaan bukan pajak (Jatmiko, 2006). Penerimaan bukan pajak contohnya seperti pemanfaatan sumber daya alam (migas), pelayanan oleh pemerintah, pengelolaan kekayaan negara dan lain-lain, yang perolehan dan sifatnya tidak stabil serta terbatas sehingga tidak bisa menjadi penerimaan utama oleh negara.

Berbeda dengan pajak, sumber penerimaan ini mempunyai umur tidak terbatas, terlebih dengan semakin bertambahnya jumlah penduduk yang semakin meningkat setiap tahunnya (Widayati dan Nurlis, 2010). Pajak merupakan sumber penerimaan Negara yang bersifat stabil dan penerimaannya juga pasti serta mencerminkan kebersamaan masyarakat dalam membiayai negara. Menurut Departemen Keuangan besarnya peran pajak dalam membiayai pembangunan tercermin dari jumlah peneriman pajak setiap tahun yang berjumlah rata-rata sebesar 75 persen dari total penerimaan negara dalam memenuhi Anggaran Pendapatan dan Belanja Negara (APBN). Berikut ini adalah presentase penerimaan pajak terhadap Pendapatan Negara dalam tiga tahun terakhir:

Tabel 1.

Laporan Penerimaan Pendapatan Negara dan Penerimaan Pajak Berdasarkan Anggaran Pendapatan Belanja Negara Tahun 2015-2017

\begin{tabular}{cccc}
\hline $\begin{array}{c}\text { Tahun } \\
\text { Anggaran }\end{array}$ & $\begin{array}{c}\text { Pendapatan Negara } \\
\text { (Triliyun Rupiah) }\end{array}$ & $\begin{array}{c}\text { Pajak } \\
\text { (Triliyun Rupiah) }\end{array}$ & $\begin{array}{c}\text { Pajak Pendapatan } \\
\text { Negara }(\%)\end{array}$ \\
\hline 2015 & $1.793,6$ & $1.201,7$ & 67,0 \\
2016 & $1.822,5$ & $1.360,2$ & 75,0 \\
2017 & $1.750,3$ & $1.489,9$ & 85,6 \\
\hline
\end{tabular}

Sumber : www.depkeu.go.id/APBN2017-2015

Mengingat besarnya jumlah pajak yang diterima dari wajib pajak, hal ini berimbas juga terhadap pendapatan Negara setiap tahunnya. Jumlah wajib pajak potensial cenderung semakin bertambah setiap tahun. Masyarakat atau wajib pajak yang sadar dengan melakukan pembayaran pajak akan meningkatkan kesejahteraan masyarakat menunjukkan bahwa mereka ingin ikut berpartisipasi 
dalam menunjang pembangunan negara. Tidak menutup kemungkinan bahwa kesadaran wajib pajak untuk membayar pajak semakin turun dengan melakukan penundaan pembayaran pajak dan pengurangan beban pajak sehingga menyebabkan penerimaan Negara atas pajak semakin menurun. Bila setiap wajib pajak sadar akan kewajibannya untuk membayar pajak, tentunya penerimaan negara atas pajak akan terus meningkat, bukan berkurang, sebab jumlah wajib pajak potensial cenderung semakin bertambah setiap tahun.

Pemahaman wajib pajak terhadap peraturan perpajakan adalah cara wajib pajak dalam memahami peraturan perpajakan yang telah ada (Hardiningsih dan Yulianawati, 2011). Fenomena yang terjadi saat ini adalah masih banyaknya wajib pajak yang belum memahami akan peraturan pajak. Seorang wajib pajak dapat dikatakan patuh dalam kegiatan perpajakan perlu memahami secara penuh tentang peraturan perpajakan antara lain mengetahui dan berusaha memahami UndangUndang Perpajakan, cara pengisian formulir perpajakan, cara menghitung pajak, selalu membayar pajak tepat waktu, cara melaporkan SPT. Pada fenomena yang terjadi tersebut memiliki pengaruh yang besar terhadap seseorang dalam memenuhi kewajibannya dalam perpajakan.

Pengetahuan wajib pajak terhadap peraturan perpajakan dapat dikatakan belum semua wajib pajak memahami, masih ada wajib pajak yang menunggu ditagih baru membayar pajak, seperti peraturan pajak pada periode lama. Hal ini dapat menurunkan jumlah penerimaan pajak negara serta tingkat kepatuhan wajib pajak. Sejak terbitnya Undang-undang Nomor 6 Tahun 1983, kemudian diubah dengan UU No. 28 Tahun 2007 tentang Ketentuan Umum dan Tata Cara 
Perpajakan (KUP) dikenal istilah Self Assessment System yang memberikan kepercayaan kepada wajib pajak untuk menghitung, membayar, dan melaporkan sendiri pajak terutangnya. Dianutnya sistem Self Assessment System, maka selain bergantung pada kesadaran dan kejujuran wajib pajak, pengetahuan teknis perpajakan yang memadai juga memegang peran penting, agar wajib pajak dapat melaksanakan kewajiban perpajakannya dengan baik dan benar, karena melalui sistem ini, setiap wajib pajak di wajibkan mengisi sendiri dan menyampaikan Surat Pemberitahuan (SPT) Tahunan dengan benar, lengkap, dan jelas (Nugroho, 2012).

Wajib pajak yang tidak memahami peraturan perpajakan secara jelas cenderung akan menjadi wajib pajak yang tidak taat. Semakin paham wajib pajak terhadap peraturan perpajakan, maka semakin paham pula wajib pajak terhadap sanksi yang akan diterima bila melalaikan kewajiban perpajakan mereka. Wajib pajak yang benar-benar paham, mereka akan mengetahui sanksi adminstrasi dan sanksi pidana sehubungan dengan SPT dan NPWP. Pemahaman wajib pajak mengenai aturan dan ketentuan perpajakan yang berlaku di Indonesia diharapkan akan meningkatkan kepatuhan pajak.

Kepatuhan wajib pajak dapat diukur dari pemahaman terhadap semua ketentuan peraturan perundang-undangan perpajakan, mengisi formulir dengan lengkap dan jelas, menghitung jumlah pajak yang terutang dengan benar, membayar dan melaporkan pajak yang terutang tepat pada waktunya. Penelitian sebelumnya menunjukkan bahwa pengetahuan pajak penting dalam rangka meningkatkan tingkat kepatuhan pajak yang artinya wajib pajak lebih bersedia 
untuk mematuhi aturan dan ketentuan yang berlaku jika mereka memahami konsep dasar perpajakan (Hardiningsih dan Yulianawati, 2011).

Tahun 2015, wajib pajak (WP) yang terdaftar dalam sistem administrasi Direktorat Jendral Pajak (DJP) mencapai 30.044.103 Wajib Pajak, yang terdiri dari 2.472.632 Wajib Pajak Badan, 5.239.385 Wajib Pajak Orang Pribadi (WPOP) Non Karyawan, dan 22.332.086 WPOP Karyawan. Hal ini cukup memperihatinkan mengingat menurut data Badan Pusat Statistik (BPS), hingga tahun 2015, jumlah penduduk Indonesia yang bekerja mencapai 93,72 juta orang, artinya baru sekitar 29,4 persen dari total jumlah orang pribadi pekerja dan berpenghasilan di Indonesia yang mendaftarkan diri atau terdaftar sebagai Wajib Pajak. Berikut ini adalah presentase kepatuhan wajib pajak orang pribadi terdaftar terhadap pelaporan SPT tahunan orang pribadi lima tahun terakhir seperti pada Tabel 2 berikut.

Tabel 2.

Jumlah Wajib Pajak Orang Pribadi yang Terdaftar dan Kepatuhan Pelaporan SPT Tahunan Orang pribadi Di Kantor Pelayanan Pajak Pratama Badung Utara 2013-2017

\begin{tabular}{cccccccc}
\hline Tahun & $\begin{array}{c}\text { Jumlah } \\
\text { WPOP }\end{array}$ & $\begin{array}{c}\text { WPOP } \\
\text { Efektif }\end{array}$ & Manual & E-Filling & E-SPT & Tota & $\begin{array}{c}\text { Kepatuhan } \\
(\%)\end{array}$ \\
\cline { 7 - 9 } 2013 & 49.887 & 34.052 & 23.756 & 5 & - & 23.761 & 69,78 \\
2014 & 53.842 & 37.776 & 21.743 & 2.817 & - & 24.560 & 65,01 \\
2015 & 57.822 & 40.011 & 16.622 & 8.475 & - & 25.097 & 62,73 \\
2016 & 60.781 & 44.916 & 11.206 & 9.765 & 987 & 21.958 & 48,88 \\
2017 & 98.446 & 89.334 & 645 & 23.786 & 26.890 & 51.321 & 57,45 \\
\hline
\end{tabular}

Berdasarkan Tabel 2 menunjukkan bahwa jumlah WPOP yang terdaftar dan efektif meningkat dari tahun 2013-2017, yang berarti bahwa wajib pajak 
memiliki itikad baik untuk memenuhi kewajiban perpajakan dengan tahap awal yaitu mendaftarkan diri untuk mendapatkan nomor pokok wajib pajak (NPWP) sebagai sarana untuk melakukan kewajiban perpajakannya. Menurut data di atas, pada tahun 2013-2016 SPT tahunan OP yang dilaporkan mengalami penurunan tiap tahunnya meskipun jumlah WPOP yang terdaftar mengalami peningkatan. Pelaporan SPT di Kantor Pelayanan Pajak Pratama Badung Utara, baru mengalami peningkatan di tahun 2017 meskipun hanya 8,57 persen, peningkatan di tahun 2017 disebabkan karena adanya tax amnesty.

Akumulasi presentase kepatuhan WPOP terdaftar terhadap pelaporan SPT OP mengalami penurunan dari tahun 2013-2016. Penurunan tersebut di akibatkan oleh masih banyaknya wajib pajak yang belum memiliki kesadaran penuh dalam melaksanakan kewajibannya sebagai wajib pajak.

Peningkatan kepatuhan wajib pajak juga dapat dipengaruhi oleh preferensi wajib pajak akan risiko-risiko yang terjadi pada setiap wajib pajak. Risiko-risiko yang terdapat pada wajib pajak dalam kaitannya untuk peningkatan kepatuhan wajib pajak antara lain adalah, risiko keuangan, risiko kesehatan, risiko sosial, risiko pekerjaan dan risiko keselamatan. Menghadapi risiko-risiko yang terjadi setiap wajib pajak harus memiliki suatu keputusan untuk menghadapi suatu risiko.

Fenomena yang terjadi, terdapat wajib pajak yang cenderung menghadapi risiko yang ada dan terdapat pula menghindari risiko yang muncul dalam perpajakan. Hal ini dapat berpengaruh terhadap seorang wajib pajak dalam meningkatkan kepatuhan wajib pajak. Tindakan untuk mengambil keputusan 
dalam menghadapi risiko yang muncul ataupun menghindari risiko yang dapat terjadi pada wajib pajak dinamakan sebagai preferensi risiko, akan tetapi tidak sedikit wajib pajak yang mengabaikan hal tersebut sehingga kepatuhan mereka sebagai wajib pajak tidak berjalan maksimal.

Penelitian yang dilakukan oleh Hardiningsih dan Yulianawati (2011) menunjukkan bahwa Pemahaman Peraturan Wajib Pajak secara parsial tidak berpengaruh pada kepatuhan wajib pajak. Hasil lain ditunjukkan oleh penelitian yang dilakukan oleh Yadnyana dan Sudiksa (2011) menyatakan bahwa Pemahaman Peraturan Perpajakan signifikan berpengaruh pada kepatuhan wajib pajak. Penelitian serupa oleh Widayati dan Nurlis (2010), menunjukkan bukti bahwa pengetahuan dan pemahaman tentang peraturan perpajakan berpengaruh terhadap Kepatuhan membayar pajak. Penelitian ini didukung dengan penelitian yang dilakukan Nugroho (2012), juga menunjukkan bahwa pengetahuan pajak berpengaruh terhadap kepatuhan wajib pajak. Pengetahuan dan pemahaman wajib pajak mengenai peraturan perpajakan berkaitan dengan persepsi wajib pajak dalam menentukan perilakunya (perceived control behavior) dalam kepatuhan untuk membayar pajak.

Semakin tinggi pengetahuan dan pemahaman wajib pajak, maka wajib pajak dapat menentukan perilakunya dengan lebih baik dan sesuai dengan ketentuan perpajakan sehingga wajib pajak memiliki tingkat kepatuhan yang tinggi, namun jika wajib pajak tidak mengerti mengenai peraturan dan proses perpajakan, maka wajib pajak tidak dapat menentukan perilakunya dengan tepat sehingga kepatuhan yang dimiliki wajib pajak rendah. Berdasarkan 
ketidakkonsistensian hasil penelitian sebelumnya maka dirasa perlu menambahkan variabel lain sebagai variabel moderating yaitu variabel preferensi resiko.

Penelitian yang dilakukan Alabede et al., (2011), menunjukkan bahwa preferensi risiko berpengaruh positif terhadap kepatuhan wajib pajak orang pibadi. Berbanding terbalik dengan hasil penelitian Ardyanto dan Utaminingsih (2014) variabel preferensi risiko berpengaruh signifikan dan negatif terhadap kepatuhan wajib pajak di Kecamatan Blora. Pada penelitian yang dilakukan Syamsudin (2014) menunjukkan hasil yang berlawanan bahwa preferensi risiko berpengaruh positif dan signifikan terhadap kepatuhan wajib pajak orang pribadi.

Penelitian Aryobimo dan Cahyonowati (2012) membuktikan preferensi risiko memberi pengaruh positif terhadap kepatuhan wajib pajak. Penelitian Adiasa (2013) memberikan hasil penelitian bahwa preferensi risiko pada hubungan pemahaman tentang peraturan perpajakan terhadap kepatuhan wajib pajak tidak memberi pengaruh terhadap kepatuhan wajib pajak serta tidak bisa memoderasi hubungan pada kedua variabel tersebut. Berdasarkan hasil penelitian sebelumnya yang tidak konsisten maka tujuan penelitian ini adalah untuk memperoleh bukti emperis apakah pemahaman peraturan pajak berpengaruh positif terhadap kepatuhan wajib pajak orang pribadi wilayah Badung Utara dan untuk memperoleh bukti emperis apakah preferensi risiko dapat memoderasi hubungan antara pemahaman tentang peraturan pajak terhadap kepatuhan wajib pajak orang pribadi wilayah Badung Utara. 
Berdasarkan pada tujuan penelitian, kajian-kajian teori relevan dan hasilhasil penelitian sebelumnya, maka hipotesis yang diajukan untuk penelitian ini adalah sebagai berikut :

$\mathrm{H}_{1}$ : Pemahaman tentang peraturan perpajakan berpengaruh positif terhadap Kepatuhan wajib pajak orang pribadi.

$\mathrm{H}_{2}$ : Preferensi Risiko memoderasi hubungan antara pemahaman wajib pajak tentang peraturan perpajakan dengan kepatuhan wajib pajak.

\section{METODE PENELITIAN}

Jenis penelitian ini merupakan penelitian asosiatif kausal. Penelitian asosiatif kausal adalah penelitian yang memiliki tujuan mengetahui pengaruh variabel bebas dengan variabel terikat. Pendekatan ini menyatakan pengaruh antara variabel independen yaitu pemahaman peraturan perpajakan, pada variabel dependen yaitu kepatuhan wajib pajak dengan preferensi resiko sebagai variabel moderasi. Desain dari penelitian ini seperti pada Gambar 1 berikut.

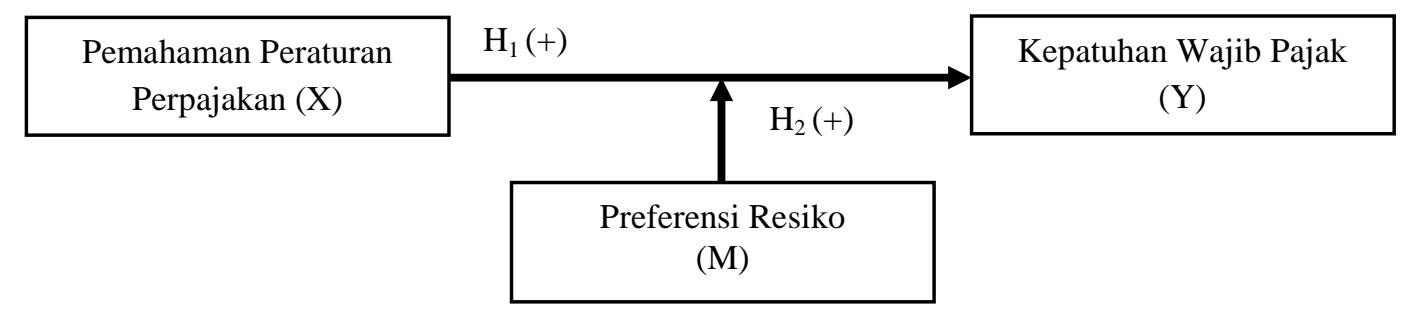

Sumber : Data diolah, 2018

\section{Gambar 1. Desain Penelitian}

Penelitian ini dilakukan pada KPP Pratama Badung Utara yang beralamat di J1. A. Yani No. 100 Denpasar. Lokasi kawasan badung utara memiliki wilayah strategis yang memiliki daerah marginal serta banyaknya kawasan industri sehingga dapat dijadikan perbandingan apakah perbedaan tingkat pemahaman masyarakat tentang peraturan perpajakan di kawasan tersebut dapat 
mempengaruhi kepatuhan wajib pajak. Objek penelitian ini adalah pemahaman peraturan perpajakan terhadap kepatuhan wajib pajak orang pribadi dengan preferensi resiko sebagai variabel moderating di KPP Pratama Badung Utara.

Penelitian ini menggunakan 3 jenis variabel yaitu variabel terikat, variabel bebas dan variabel moderasi yang dapat dilihat pada Tabel 3 berikut.

Tabel 3.

Rangkuman Variabel dan Indikator Penelitian

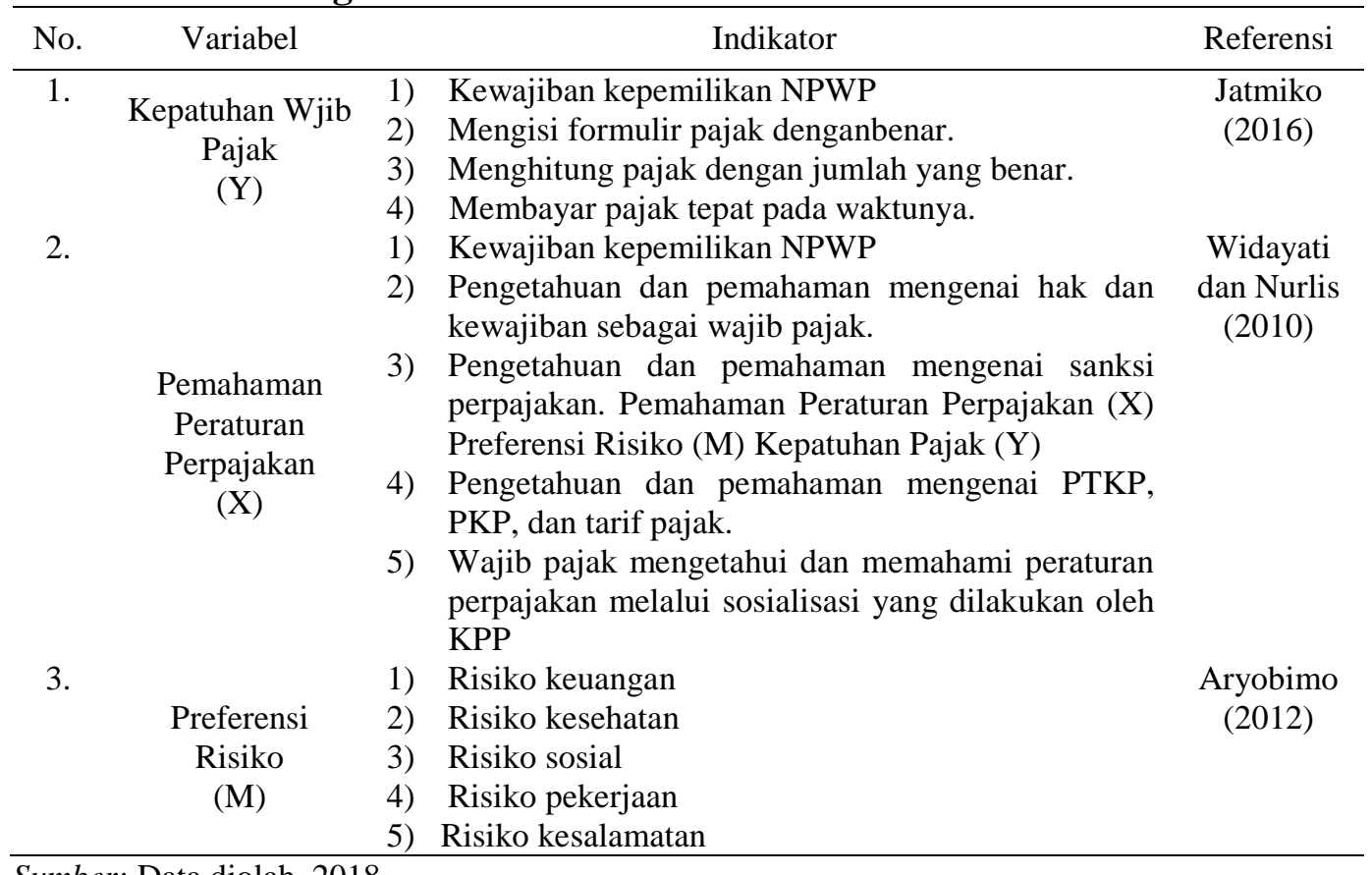

Wajib pajak orang pribadi yang terdaftar di KPP Pratama Badung Utara menjadi populasi dalam penelitian ini. Penelitian ini menggunakan metode accidential sampling. Accidental sampling adalah mengambil responden sebagai sampel secara kebetulan, yaitu siapa secara kebetulan bertemu dengan peneliti dapat digunakan sebagai sampel bila orang yang kebetulan ditemui cocok sebagai sumber data (Sugiyono, 2017). Kriteria responden yang menjadi sampel dalam 
penelitian ini adalah seluruh wajib pajak orang pribadi yang terdaftar di KPP Pratama Badung Utara.

Besarnya ukuran sampel dihitung dengan menggunakan rumus Slovin, sehingga diperoleh jumlah sampel minimal yang digunakan dalam penelitian ini sebanyak 73, namun dalam penelitian ini digunakan sebanyak 100 (seratus) wajib pajak orang pribadi di KPP Pratama Badung Utara. Teknik pengumpulan data dilakukan dengan cara memberikan seperangkat pernyataan tertulis (kuesioner) kepada responden untuk dijawab. Instrumen penelitian yang sudah terkumpul selanjutnya diuji menggunakan uji validitas dan uji reliabilitas. Data yang dinyatakan valid selanjutnya diuji menggunakan uji asumsi klasik agar variabel yang dioperasikan memenuhi persyaratan sehingga tidak menimbulkan hasil yang bias dalam pengujian.

Metode analisis data yang digunakan untuk mengetahui pengaruh pemahaman peraturan terhadap kepatuhan pajak dengan preferensi resiko sebagai variabel pemoderasi adalah Moderated Regression Analysis (MRA) dengan menggunakan Uji Selisih Nilai Mutlak. Alasan menggunakan uji interaksi ini adalah adanya variabel moderating dalam penelitian ini yaitu melihat pengaruh pemahaman peraturan perpajakan terhadap kepatuhan wajib pajak orang pribadi dengan preferensi resiko sebagai variabel moderating. Uji selisih nilai mutlak dilakukan dengan cara mencari selisih nilai mutlak terstandarisasi diantara kedua variabel bebasnya. Jika selisih nilai mutlak diantara kedua variabel bebas tersebut signifikan positif maka variabel tersebut memoderasi hubungan antara variabel 
bebas dan variabel tergantungnya (Eka, 2015). Persamaan Regresi untuk penelitian ini adalah sebagai berikut:

$\mathrm{Y}=\alpha+\beta_{1} \mathrm{X}_{1}+\beta_{2} \mathrm{X}_{2}+\beta_{3} \mathrm{X}_{1}^{*} \mathrm{X}_{2}+\varepsilon_{1}$

Keterangan:

$\mathrm{Y} \quad=$ Kepatuhan wajib pajak

$\alpha=$ Konstanta

$\beta_{1} \ldots \beta_{3}=$ Koefisien regresi

$\mathrm{X}_{1}=$ Pemahaman peraturan perpajakan

$\mathrm{X}_{2}=$ Preferensi Resiko

$\varepsilon_{1} \quad=$ Variabel pengganggu (error)

\section{HASIL DAN PEMBAHASAN}

Kuesioner yang disebar dalam penelitian ini sebanyak 100 kuesioner. Ringkasan pengiriman dan pengembalian kuesioner penelitian ditunjukkan dalam Tabel 4 berikut.

Tabel 4.

Rincian Pengiriman dan Pengembalian Kuesioner

\begin{tabular}{lc}
\hline \multicolumn{1}{c}{ Keterangan } & Jumlah Kuesioner \\
\hline Kuesioner yang diantar langsung & 100 \\
Kueisioner yang tidak dikembalikan & 0 \\
Kuesioner yang dikembalikan & 100 \\
Kuisioner yang digugurkan & 0 \\
Kuisioner yang digunakan & 100 \\
Tingkat pengembalian yang digunakan (usable respon rate) $: 100 / 100 \times 100 \%=100 \%$ \\
Sumber : Data diolah, 2018
\end{tabular}

Rincian pengiriman dan pengembalian kuesioner ditunjukkan pada Tabel 4 menunjukkan bahwa jumlah kuesioner yang disebar adalah sebanyak 100 kuesioner, semua kuesioner diantar langsung. Dari jumlah tersebut yang dikembalikan sebanyak 100 kuesioner. Kuesioner yang layak digunakan sebanyak 100 kuesioner. Dengan demikian respons rate 100 persen sangat layak mewakili 
populasi. Selanjutnya, karakteristik responden yang berpartisipasi dalam penelitian ini ditunjukkan dalam Tabel 5.

Tabel 5.

Karakteristik Responden

\begin{tabular}{clcc}
\hline No & Keterangan & $\begin{array}{c}\text { Jumlah } \\
\text { (orang) }\end{array}$ & $\begin{array}{c}\text { Persentase } \\
(\%)\end{array}$ \\
\hline 1 & Jenis Kelamin & & \\
& Lak-laki & 60 & 60 \\
& Perempuan & 40 & 40 \\
2. & Usia & & \\
& 20-25 Th & 10 & 10 \\
& 26-30 Th & 15 & 15 \\
& 31-40 Th & & 20 \\
& >40 Th & 20 & 55 \\
3. & Pendidikan & 55 & \\
& SMA & & 5 \\
& Diploma & 5 & 15 \\
& Sarjana & 15 & 80 \\
& Jumlah & 80 & 100 \\
\hline
\end{tabular}

Sumber : Data diolah, 2018

Berdasarkan tabel diatas diketahui wajib pajak yang terdaftar di KPP Pratama Badung Utara sebagian besar adalah laki-laki (60 persen), hal ini dapat dikaitkan dengan laki-laki yang lebih banyak menjadi tulang punggung ekonomi bagi keluarga sehingga laki-laki lebih banyak terdaftar sebagai wajib pajak.

Umur responden menggambarkan tingkat kedewasaan seseorang dalam melakukan aktivitas yang akan mempengaruhi emosi untuk mengambil keputusan yang dikehendaki dalam suatu organisasi ataupun perorangan. Berdasarkan tabel di atas, responden yang berumur $>40$ tahun sebanyak 55 orang ( 55 persen).

Tingkat pendidikan responden dapat digunakan sebagai indikator untuk mengetahui tingkat pengetahuan dan intelektualitas yang dimiliki. Dengan mengetahui tingkat pendidikannya, dapat digambarkan pola pikir yang dimilki oleh responden. Berdasarkan tabel di atas, responden yang tingkat pendidikannya sarjana sebanyak 80 orang ( 80 persen). 
Statistik deskriptif dalam penelitian ini disajikan untuk memberikan informasi mengenai karakteristik variabel-variabel penelitian, antara lain minimum, maksimum, mean, dan standar deviasi. Hasil statistik deskriptif dapat dilihat pada Tabel 6 sebagai berikut.

Tabel 6.

Hasil Statistik Deskriptif

\begin{tabular}{cccccc}
\hline & N & Minimum & Maximum & Mean & $\begin{array}{c}\text { Std. } \\
\text { Devitiation }\end{array}$ \\
\hline X & 100 & & 42,00 & 29,5700 & 4,52659 \\
M & 100 & 22,00 & 44,00 & 32,3700 & 6,59760 \\
Y & 100 & 22,00 & 40,00 & 28,9600 & 5,54672 \\
Valid N & 100 & 19,00 & & & \\
(listwise) & & & & & \\
\hline Sumber: & & & &
\end{tabular}

Sumber: Data diolah, ,2018

Berdasarkan tabel di atas dapat dilihat nilai minimum untuk pemahaman peraturan perpajakan adalah 22 dan nilai maksimumnya adalah 42. Mean untuk pemahaman peraturan perpajakan adalah 29,57, hal ini berarti rata-rata pemahaman peraturan perpajakan sebesar 29,57. Standar deviasinya 4,52, hal ini berarti terjadi penyimpangan pemahaman peraturan perpajakan terhadap nilai rata-ratanya yaitu sebesar 4,56 .

Untuk variabel preferensi risiko nilai minimumnya adalah 22 dan nilai maksimumnya adalah 44. Mean variabel preferensi risiko adalah 32,37, hal ini berarti bahwa rata-rata nilai preferensi risiko sebesar 32,37 Standar deviasinya sebesar 6,50, hal ini berarti terjadi penyimpangan nilai preferensi risiko terhadap nilai rata-ratanya sebesar 6,50 . Selanjutnya, variabel kepatuhan wajib pajak nilai minimumnya adalah 19 dan nilai maksimumnya adalah 40. Mean variabel kepatuhan wajib pajak adalah 28,96, hal ini berarti rata-rata kepatuhan wajib pajak sebesar 28,96. Standar deviasinya sebesar 5,54. Hal ini berarti terjadi penyimpangan kepatuhan wajib pajak terhadap nilai rata-ratanya sebesar 5,54. 
Pengujian instrumen yang digunakan dalam penelitian ini adalah uji validitas dan uji reliabilitas yang dapat dilihat pada Tabel 7 berikut.

Tabel 7.

Hasil Uji Validitas dan Reliabilitas

\begin{tabular}{|c|c|c|c|c|}
\hline Variabel & Item & Pearson Correlation & Cronbach Alpha & Keterangan \\
\hline Pemahaman & X.1 & 0,581 & 0,946 & Valid dan reliabel \\
\hline Peraturan & X.2 & 0,636 & & Valid dan reliabel \\
\hline \multirow[t]{9}{*}{ Perpajakan } & X.3 & 0,685 & & Valid dan reliabel \\
\hline & X.4 & 0,789 & & Valid dan reliabel \\
\hline & X.5 & 0,685 & & Valid dan reliabel \\
\hline & X.6 & 0,443 & & Valid dan reliabel \\
\hline & X.7 & 0,590 & & Valid dan reliabel \\
\hline & X.8 & 0,528 & & Valid dan reliabel \\
\hline & X.9 & 0,800 & & Valid dan reliabel \\
\hline & X.10 & 0,792 & & Valid dan reliabel \\
\hline & $\mathrm{X} .11$ & 0,581 & & Valid dan reliabel \\
\hline \multirow{11}{*}{$\begin{array}{l}\text { Preferensi } \\
\text { risiko }\end{array}$} & M.1 & 0,633 & 0,968 & Valid dan reliabel \\
\hline & M.2 & 0,633 & & Valid dan reliabel \\
\hline & M.3 & 0,662 & & Valid dan reliabel \\
\hline & M.4 & 0,575 & & Valid dan reliabel \\
\hline & M.5 & 0,599 & & Valid dan reliabel \\
\hline & M.6 & 0,413 & & Valid dan reliabel \\
\hline & M.7 & 0,462 & & Valid dan reliabel \\
\hline & M.8 & 0,554 & & Valid dan reliabel \\
\hline & M.9 & 0,509 & & Valid dan reliabel \\
\hline & M.10 & 0,696 & & Valid dan reliabel \\
\hline & M.11 & 0,633 & & Valid dan reliabel \\
\hline Kepaatuhan & Y1 & 0,869 & 0,957 & Valid dan reliabel \\
\hline \multirow[t]{9}{*}{ wajib pajak } & Y2 & 0,868 & & Valid dan reliabel \\
\hline & Y3 & 0,867 & & Valid dan reliabel \\
\hline & Y4 & 0,752 & & Valid dan reliabel \\
\hline & Y5 & 0,822 & & Valid dan reliabel \\
\hline & Y6 & 0,802 & & Valid dan reliabel \\
\hline & Y7 & 0,902 & & Valid dan reliabel \\
\hline & Y8 & 0,888 & & Valid dan reliabel \\
\hline & Y9 & 0,901 & & Valid dan reliabel \\
\hline & Y10 & 0,865 & & Valid dan reliabel \\
\hline
\end{tabular}

Sumber : Data diolah, 2018

Berdasarkan Tabel 7 dapat dilihat bahwa Hasil uji validitas menunjukkan nilai di atas 0,3. Hal ini bermakna bahwa instrumen pemahaman peraturan perpajakan, preferensi risiko dan kepatuhan wajib pajak adalah valid. Hasil juga menunjukkan ketiga instrumen di atas yaitu pemahaman peraturan perpajakan, preferensi resiko, dan kepatuhan wajib pajak menunjukkan bahwa nilai Cronbach Alpha $>0,60$. Hal ini berarti bahwa instrumen yang digunakan adalah reliabel. 
Analisis regresi sangat memerlukan bagian asumsi agar model dapat digunakan sebagai alat prediksi baik. Oleh karena itu dalam penelitian ini dilakukan uji asumsi klasik yang meliputi uji normalitas, dan uji heteroskedastisitas. Hasil uji normalitas dalam penelitian ini diuji menggunakan uji Kolmogorov-Smirnov yang dapat dilihat pada Tabel 8 sebagai berikut.

Tabel 8.

Hasil Uji Kolmogorov - Smirnov

\begin{tabular}{cc}
\hline & Unstandardized Residual \\
\hline $\mathrm{N}$ & 100 \\
Kolmogorov-Smirnov $Z$ & 0,882 \\
Asymp.Sig.(2-tailed) & 0,167 \\
\hline
\end{tabular}

Sumber : Data diolah, 2018

Berdasarkan Tabel 8 dapat dilihat bahwa nilai Kolmogorov Smirnov (K-S) sebesar 0,882, sedangkan nilai Asymp. Sig. (2-tailed) sebesar 0,167. Hasil tersebut mengindikasikan bahwa model persamaan regresi tersebut berdistribusi normal karena nilai Asymp. Sig (2-tailed) 0,167 lebih besar dari nilai alpha 0.05.

Model regresi yang baik adalah yang tidak mengandung gejala heteroskedastisitas atau mempunyai variasn yang homogeny. Dalam penelitian ini menggunakan pengujian dengan uji Glesjer. Jika signifikansi t dari hasil meregresi nilai absolute residual terhadap variabel bebas lebih dari 0,05 maka model regresi tidak mengandung heteroskedastisitas. Selanjutnya Hasil uji heteroskedastisitas dapat dilihat pada Tabel 9 sebagai berikut.

Tabel 9.

Hasil Uji Heteroskedastisitas

\begin{tabular}{|c|c|c|c|c|c|c|}
\hline \multirow{2}{*}{\multicolumn{2}{|c|}{ Model }} & \multicolumn{2}{|c|}{ Unstandardized Coefficients } & \multirow{2}{*}{$\begin{array}{c}\begin{array}{c}\text { Standardized } \\
\text { Coefficients }\end{array} \\
\text { Beta }\end{array}$} & \multirow[t]{2}{*}{$\mathrm{T}$} & \multirow[t]{2}{*}{ Sig. } \\
\hline & & B & Std. Error & & & \\
\hline \multirow[t]{4}{*}{1} & (Constant) & 7,317 & 5,218 & & 1,402 & 0,164 \\
\hline & $X$ & 0,071 & 0,037 & 0,916 & 1,883 & 0,063 \\
\hline & M & 0,061 & 0,034 & 1,157 & 1,802 & 0,075 \\
\hline & X.M & $-1,628$ & 1,081 & $-1,350$ & $-1,506$ & 0,135 \\
\hline
\end{tabular}

Sumber : Data diolah, 2018 
Berdasarkan hasil tersebut dapat dilihat bahwa nilai signifikansi masingmasing variabel di atas $\alpha=0,05$ yang berarti tidak terdapat pengaruh antara variabel bebas terhadap absolute residual. Jadi, dapat disimpulkan bahwa model regresi tidak mengandung adanya heteroskedastisitas.

Pengujian ini bertujuan untuk menguji hubungan antara pengaruh antara satu variabel independen dengan dependen. Uji ini digunakan untuk mengetahui mengetahui pengaruh pemahaman peraturan perpajakan $(\mathrm{X})$ yang di moderasi oleh preferensi resiko (M), pada kepatuhan wajib pajak (Y). Hasil pengujian hipotesis kedua dapat dilihat pada Tabel 10 sebagai berikut:

Tabel 10.

Hasil Analisis Regresi Linear Berganda

\begin{tabular}{|c|c|c|c|c|c|c|}
\hline \multirow{2}{*}{\multicolumn{2}{|c|}{ Model }} & \multicolumn{2}{|c|}{ Unstandardized Coefficients } & \multirow{2}{*}{$\begin{array}{c}\begin{array}{c}\text { Standardized } \\
\text { Coefficients }\end{array} \\
\text { Beta }\end{array}$} & \multirow[t]{2}{*}{$\mathrm{T}$} & \multirow[t]{2}{*}{ Sig. } \\
\hline & & B & Std. Error & & & \\
\hline \multirow[t]{4}{*}{1} & (Constant) & $-23,613$ & 6,990 & & $-3,378$ & 0,001 \\
\hline & $\mathrm{X}$ & 0,044 & 0,015 & 0,036 & 2,93 & 0,004 \\
\hline & M & 0,655 & 0,045 & 0,780 & 14,420 & 0,000 \\
\hline & X.M & 4,400 & 1,448 & 0,229 & 3,040 & 0,003 \\
\hline \multicolumn{2}{|c|}{ F hitung } & \multicolumn{2}{|c|}{$5.112,097$} & & & \\
\hline \multicolumn{2}{|c|}{ Signifikansi F } & \multicolumn{2}{|c|}{0,000} & & & \\
\hline \multicolumn{2}{|c|}{ R Square } & \multicolumn{2}{|c|}{0,804} & & & \\
\hline \multicolumn{2}{|c|}{ Adjusted R Square } & \multicolumn{2}{|c|}{0,794} & & & \\
\hline
\end{tabular}

Sumber : Data diolah, 2018

Berdasarkan Tabel 10 dapat dibuat suatu model persamaan regresi yaitu sebagai berikut :

$$
Y=-23,613+0,044 X+0,655 M+4,400 X^{*} M+e
$$

Nilai koefisien regresi pemahaman peraturan perpajakan (X) sebesar 0,044, menunjukkan bahwa terdapat pengaruh positif antara variabel pemahaman perpajakan (X) terhadap variabel kepatuhan wajib pajak orang pribadi (Y) sebesar 0,044. Nilai koefisien regresi preferensi resiko (M) sebesar 0,655, menunjukkan bahwa terdapat pengaruh positif antara variabel preferensi resiko (M) terhadap 
variabel kepatuhan wajib pajak orang pribadi sebesar 0,655. Nilai koefisien regresi (XM) sebesar 4,400, menunjukkan bahwa dengan adanya preferensi resiko (M) maka pengaruh pemahaman peraturan perpajakan (X) terhadap kepatuhan wajib pajak orang pribadi (Y) akan semakin diperkuat.

Berdasarkan Tabel 10, dapat disimpulkan bahwa besarnya nilai koefisien determinasi ditunjukkan dengan nilai adjusted $\mathrm{R}$ square $\left(\mathrm{R}^{2}\right)$ adalah 0,794 . Hasil ini berarti bahwa pengaruh variabel pemahaman peraturan perpajakan (X), Preferensi Resiko (M), interaksi X.M, terhadap kepatuhan wajib pajak (Y) sebesar 79,4 persen dan sisanya 20,6 persen dipengaruhi oleh faktor-faktor lain di luar model penelitian. Tabel 10 juga menunjukkan bahwa nilai dari F hitung 5.112,097 dengan nilai signifikansi 0,000 (kurang dari 0,05) maka disimpulkan bahwa ada pengaruh yang signifikan dari variabel independen terhadap variabel dependen secara simultan (bersama-sama). Sehingga model penelitian katakan layak digunakan sebagai model regresi moderasi.

Berdasarkan hasil hasil uji t dan nilai signifikansi pada variabel pemahaman peraturan perpajakan $(\mathrm{X})$ dalam Tabel 10 menunjukkan nilai sig lebih kecil dari taraf nyata dalam penelitian ini yaitu 0,05 . Hal tersebut menunjukkan bahwa pemahaman peraturan perpajakan berpengaruh positif dan signifikan terhadap kepatuhan wajib pajak orang pribadi di KPP badung utara, maka hipotesis pertama dalam penelitian ini dapat diterima.

Pengetahuan dan pemahaman tentang peraturan perpajakan merupakan penalaran dan penangkapan makna tentang peraturan perpajakan. Masyarakat hendaknya memiliki pengetahuan dan pemahaman tentang peraturan-peraturan 
perpajakan, karena untuk memenuhi kewajiban perpajakannya, pembayar pajak harus mengetahui tentang pajak terlebih dahulu. Tanpa adanya pengetahuan dan pemahaman peraturan pajak yang dimiliki masyarakat, maka masyarakat tidak mungkin mau membayar pajak. Penelitian yang dilakukan Widayati dan Nurlis (2010), menunjukkan bukti bahwa pengetahuan dan pemahaman tentang peraturan perpajakan berpengaruh terhadap Kepatuhan membayar pajak. Penelitian ini didukung dengan penelitian yang dilakukan Nugroho (2012), juga menunjukkan bahwa pengetahuan pajak berpengaruh terhadap kepatuhan wajib pajak.

Berdasarkan hasil uji t dan nilai signifikansi variabel preferensi resiko (M) dalam Tabel 10 menunjukkan nilai signifikansi lebih kecil daripada taraf nyata dalam penelitian ini yaitu 0,05 . Hal tersebut menunjukkan bahwa preferensi risiko memoderasi hubungan pemahaman peraturan perpajakan dengan dengan kepatuhan wajib pajak, maka hipotesis kedua dalam penelitian ini dapat diterima.

Seorang wajib pajak mempunyai tingkat preferensi risiko yang tinggi baik risiko kesehatan, risiko keselamatan, risiko pekerjaan maka wajib pajak tersebut cenderung untuk lebih taat dalam membayar pajak, sedangkan apabila seorang wajib pajak memiliki tingkat risiko yang rendah dalam kehidupan wajib pajak itu sendiri maka wajib pajak tersebut justru cenderung untuk lebih tidak taat dalam membayar pajak. hasil ini sejalan dengan penelitian yang dilakukan Alabede et al., (2011) kemudian diperkuat oleh penelitian Aryobimo dan Cahyonowati (2012) yang mengungkapkan bahwa Preferensi resiko memoderasi hubungan antara pemahaman peraturan perpajakan terhadap kepatuhan wajib pajak orang pribadi. 
Hasil penelitian ini diharapkan dapat memberikan pemahaman yang lebih luas mengenai pemahaman peraturan perpajakan terhadap kepatuhan dengan preferensi resiko sebagai variabel pemoderasi. Penelitian ini menghasilkan simpulan mengenai pengaruh variabel pemahaman peraturan perpajakan dan preferensi resiko berpengaruh positif dan signifikan terhadap kepatuhan wajib pajak orang pribadi.

Peningkatan kepatuhan wajib pajak di pengaruhi oleh pemahaman peraturan perpajakan juga dipengaruhi oleh preferensi wajib pajak akan risiko-risiko yang terjadi pada setiap wajib pajak. Risiko-risiko yang terdapat pada wajib pajak dalam kaitannya untuk peningkatan kepatuhan wajib pajak antara lain adalah, risiko keuangan, risiko kesehatan, risiko sosial, risiko pekerjaan dan risiko keselamatan. Menghadapi risiko-risiko yang terjadi setiap wajib pajak harus memiliki suatu keputusan untuk menghadapi suatu risiko.

Hasil dari penelitian ini diharapkan memberikan kontribusi bagi pihak-pihak yang berkepentingan khususnya bagi yang terlibar dalam upaya peningkatan kepatuhan wajib pajak orang pribadi. Hasil penelitian ini mengimplikasikan bahwa pemahaman perpaturan perpajakan wajib pajak akan berdampak besar bagi kepatuhan seorang wajib pajak.

\section{SIMPULAN}

Simpulan yang dapat diberikan berdasarkan hasil penelitian yang dilakukan yaitu pertama, Pemahaman peraturan perpajakan berpengaruh positif dan signifikan terhadap kepatuhan wajib pajak. Hal ini berarti semakin tinggi pemahaman wajib 
pajak tentang peraturan perpajakan maka kepatuhan wajib pajak akan semakin tinggi sehingga, hipotesis pertama dalam penelitian ini diterima. Kedua, Preferensi risiko merupakan varibel yang dapat memoderasi hubungan pemahaman peraturan perpajakan dengan kepatuhan wajib pajak. Hal ini berarti moderasi yang diberikan akan memperkuat hubungan antara pemahaman peraturan perpajakan terhadap kepatuhan wajib pajak sehingga, hipotesis kedua dalam penelitian ini diterima.

Berdasarkan hasil penelitian dan simpulan yang diperoleh serta keterbatasan penelitian yang ada, maka saran yang dapat berikan yaitu bagi KPP Pratama Badung Utara diharapkan agar memberikan sosialisasi perpajakan kepada seluruh wajib pajak secara kesinambungan, sehingga wajib pajak akan lebih memahami mengenai arti penting pajak. Dengan demikian akan lebih meningkatkan kesadaran dan juga kepatuhan dari wajib pajak.

Bagi peneliti selanjutnya yang ingin melakukan penelitian serupa, sebaiknya memperluas populasi penelitian. Populasi penelitian tidak hanya diambil pada KPP Pratama Badung Utara melainkan bisa dikembangkan pada seluruh KPP yang ada pada salah satu provinsi.

\section{REFERENSI}

Adiasa, N. (2013). Pengaruh Pemahaman Peraturan Pajak terhadap Kepatuhan Wajib Pajak dengan Preferensi Risiko sebagai Variabel Moderating. Accounting Analysis Journal, 2(3).

Alabede, J., Affrin, Z., and Idris, K. (2011). Tax Service Quality and Tax Compliance in Nigeria: Do Taxpayer's Financial Condition and Risk Preference Play Any Moderating Role. European Journal of Economics 
Finance and Administrative Sciences, 35, 90-108.

Andini, W. (2018). Persepsi Tax Amnesty Sebagai Pemoderasi Pengaruh Kendaraan Wajib Pajak dan Sanksi Perpajakan Pada Kepatuhan WPOP. EJurnal Akuntansi, 22(1).

Ardyanto, A. A., dan Utaminingsih, N. S. (2014). Pengaruh Sanksi Pajak dan Pelayanan Aparat Pajak Terhadap Kepatuhan Wajib Pajak dengan Preferensi Risiko Sebagai Variabel Moderasi.

Arikunto. (2007). Manajemen Penelitian. Jakarta: Rineka Cipta.

Aryobimo, P. T., dan Cahyonowati, N. (2012). Pengaruh Persepsi Wajib Pajak tentang Kualitas Pelayanan Fiskus terhadap Kepatuhan Wajib Pajak dengan Kondisi Keuangan Wajib Pajak dan Preferensi Risiko sebagai Variabel Moderating (Studi Empiris terhadap Wajib Pajak Orang Pribadi di Kota Semarang). Jurnal Akuntansi, 1(2).

Devano, S. dan Rahayu. (2016). Perpajakan: Konsep, Teori dan Isu. Jakarta: Kencana.

Eka, Y. (2015). Pengaruh Pemahaman Peraturan Perpajakan Terhadap Kepatuhan Formal Wajib Pajak dengan Preferensi Risiko Sebagai Variabel Moderating. Makasar: Fakultas ekonomi dan Bisnis Universitas Hasanuddin.

Ghozali, I. (2013). Aplikasi Analisis Multivariate dengan Program SPSS. Edisi Ketujuh. Semarang: Badan Penerbit Universitas Diponegoro.

Hardiningsih, P., dan Yulianawati, N. (2011). Faktor-Faktor yang Mempengaruhi Kemauan Membayar Pajak. Jurnal Dinamika Keuangan Dan Perbankan, $3(1)$.

Jatmiko, A. N. (2006). Pelaksanaan sanksi denda, Pelayanan fiskus, dan kesadaran perpajakan terhadap kepatuhan wajib pajak (studi empiris terhadap wajib pajak orang pribadi di Kota Semarang). Tesis Fakultas Ekonomi Universitas Diponegoro.

Nugroho, R. A. (2012). Faktor-Faktor yang Mempengaruhi Kemauan Untuk Membayar Pajak dengan Kesadaran Pajak Sebagai Variabel Intervening. (Studi Kasus Wajib Pajak Orang Pribadi Yang Melakukan Pekerjaan Bebas Yang Terdaftar Di KPP Pratama Semarang Tengah Satu). Skripsi Fakultas Ekonomika Dan Bisnis Universitas Diponegoro Semarang.

Resmi, S. (2013). Perpajakan Teori dan Kasus. Edisi 2. Jakarta: Salemba Empat.

Robbins, S. P. dan Judge, T. A. (2008). Perilaku Organisasi. Jakarta: Salemba Empat. 
Sugiyono. (2017). Metode Penelitian Kuantitatif, Kualitatif dan R\&D. Bandung: Alfabeta.

Syamsudin, M. (2014). Pengaruh Persepsi Wajib Pajak tentang Kualitas Pelayanan Fiskus Terhadap Kepatuhan Wajib Pajak dengan Kondisi Keuangan Wajib Pajak dan Preferensi Risiko sebagai variabel moderating (Studi Empiris terhadap Wajib pajak Orang Pribadi di Kota Semarang).

Torgler, B. (2013). Tax Morale : Theory and Analysis of Tax Compliance. Unpublished doctoral dissertion. University of Zurich Switzerland.

Umar, H. (2015). Metode Penelitian untuk Skripsi dan Tesis Bisnis. Edisi Bam ke7. Jakarta: PT Raja Grafmdo Persada.

Undang - Undang Republik Indonesia Nomor 28 Tahun 2007 tentang perubahan ketiga atas Undang - Undang Nomor 6 Tahun 1983 tentang Ketentuan Umum dan Tata Cara Perpajakan.

Widayati, dan Nurlis. (2010). Faktor-Faktor Yang Mempengaruhi Kemauan Untuk Membayar Pajak Wajib Pajak Orang Pribadi Yang Melakukan Pekerjaan Bebas ( Studi Kasus Pada Kpp Pratama Gambir Tiga). Symposium Nasional Akuntansi XIII Purwokerto.

Wirawan, N. (2002). Cara Mudah Memahami Statistik 2 (Statistik inferesia) Untitk Ekonomi dan Bisnis (2nd ed.). Denpasar: Keraras Emas.

Yadnyana, dan Sudiksa. (2011). Pengaruh Peraturan Pajak Serta Sikap Wajib Pajak Pada Kepatuhan Wajib Pajak Koperasi di Kota Denpasar. Buletin Studi Ekonomi, 17(2), 197-206. 